\title{
Simulating the spread of activation in neocortical circuits
}

\author{
Samuel A Neymotin ${ }^{1 *}$, Jason C Wester ${ }^{2}$, Diego Contreras ${ }^{2}$, William W Lytton 1,3,4 \\ From Twentieth Annual Computational Neuroscience Meeting: CNS*2011 \\ Stockholm, Sweden. 23-28 July 2011
}

Dynamics in the brain are shaped by the connectivity of neocortical circuits and by incoming sensory information. The neocortical columnar architecture has been hypothesized to be a module for shaping dynamics to perform information processing. However, the dynamics and routing of information flow between elements of neocortical columns and amongst neocortical columns remains poorly understood.

Using NEURON[1], we simulated a set of 11 horizontally connected layered neocortical columns which consisted of event-driven rule-based neurons wired according to known anatomical data and driven with random white-noise synaptic inputs [2]. We simulated afferent sensory inputs via the thalamus by strong stimulation of layer 4 pyramidal neuron AMPA/NMDA synapses in selected columns. To trace the role of different neocortical layers in information flow within and between columns, we simulated the focal application of the sodium channel blocker, tetrodotoxin (TTX), by inactivating selected layers of selected columns.

We tuned the network in order to achieve realistic cell firing rates and to avoid a high frequency of spontaneous population spikes. During baseline, a physiological frequency spectrum appeared as an emergent property, displaying dominant frequencies that were not present in either the inputs, or in the intrinsic or activated frequencies of any of the cell groups.

Thalamic stimuli evoked a brief population spike within layer 4 . This population spike recruited recurrent activation within the column, evoking a set of 4-8 population spike discharges lasting from $500-1000 \mathrm{~ms}$. The activity within the stimulated column spread in the classical neocortical column pathway: layer $4->$ layer $2 / 3 \rightarrow$

\footnotetext{
* Correspondence: samn@neurosim.downstate.edu

'Joint Biomedical Engineering Program SUNY Downstate/NYU-Poly, Brooklyn, NY, 11203, USA

Full list of author information is available at the end of the article
}

layer 5. After excitation reached layer 5, it spread to the neighboring columns by activating horizontal connections between layer 5 pyramidal cells. This activity then spread within the neighboring column from L5 to L2/3 pyramidal cells. After recurrent activation within L2/3, downward activation from L2/3 to L5 pyramidal cells initiated activity propagation from L 5 to the next neighboring column. This activation sequence led to waves of population spikes gradually spreading outward from the initially stimulated column(s).

We found that selective blockage of layer $2 / 3$ neurons via TTX simulation attenuated, but did not block the flow of activity between columns. Instead, activity was able to propagate from the stimulated L4 -> L5 pyramidal cells and then to neighboring columns via the L5 horizontal projections. When we blocked layer 5 neurons of stimulated columns, we found that activity was no longer able to flow from the stimulated to neighboring columns.

Our simulations demonstrate physiologically realistic spread of activation both within and between columns. Verifying the role of different layers in intra- and intercolumnar activation spread may be clinically relevant for containing seizures, where runaway excitation may be prevented by selective micro-ablation.

\section{Acknowledgements \\ Supported by DARPA grant N66001-10-C-2008. \\ The authors would like to thank Larry Eberle (SUNY Downstate), Yosef Skolnick, and David Campbell for Neurosim lab computer support; Ahmet Omurtag (BioSignal Group) for discussions on data analysis.}

\section{Author details}

1Joint Biomedical Engineering Program SUNY Downstate/NYU-Poly, Brooklyn, NY, 11203, USA. ²Dept. Neuroscience, University of Pennsylvania Medical School, Philadelphia, Pennsylvania, 19104, USA. ${ }^{3}$ Dept. Physiology \& Pharmacology, Biomedical Engineering, Neurology, SUNY Downstate, Brooklyn, NY 11203, USA. ${ }^{4}$ Dept. Neurology, Kings County Hospital Center, Brooklyn, NY 11203, USA.

\section{() Biomed Central}

(C) 2011 Neymotin et al; licensee BioMed Central Ltd. This is an open access article distributed under the terms of the Creative Commons Attribution License (http://creativecommons.org/licenses/by/2.0), which permits unrestricted use, distribution, and reproduction in any medium, provided the original work is properly cited. 
Published: 18 July 2011

\section{References}

1. Carnevale NT, Hines ML: The NEURON Book. NewYork: Cambridge University Press; 2006.

2. Neymotin SA, Jacobs KM, Fenton AA, Lytton WW: Synaptic information transfer in computer models of neocortical columns. J Comput Neurosci 2011, 30:69-84.

doi:10.1186/1471-2202-12-S1-P209

Cite this article as: Neymotin et al: Simulating the spread of activation

in neocortical circuits. BMC Neuroscience 2011 12(Suppl 1):P209.

Submit your next manuscript to BioMed Central and take full advantage of:

- Convenient online submission

- Thorough peer review

- No space constraints or color figure charges

- Immediate publication on acceptance

- Inclusion in PubMed, CAS, Scopus and Google Scholar

- Research which is freely available for redistribution

Submit your manuscript at www.biomedcentral.com/submit
() Biomed Central 